\title{
AFTA and the Intra-Trade Patterns among ASEAN-5 Economies:
}

\section{Trade-Enhancing or Trade-Inhibiting?}

\author{
Kim-Lan Siah \\ Department of Economics, Faculty of Economics and Management \\ Universiti Putra Malaysia, 43400 UPM Serdang, Selangor, Malaysia. \\ E-mail: audreysiah@yahoo.com \\ Chee-Keong Choong (Corresponding author) \\ Department of Economics and Finance, Faculty of Business and Finance \\ Universiti Tunku Abdul Rahman (Perak Campus) \\ Jalan Universiti, Bandar Barat, 31900 Kampar Perak Darul Ridzuan, Malaysia \\ Tel: 60-5-466-2323 E-mail: choongck@utar.edu.my \\ Zulkornain Yusop \\ Department of Economics, Faculty of Economics and Management \\ Universiti Putra Malaysia, 43400 UPM Serdang, Selangor, Malaysia. \\ Tel: 60-3-8946-7631 E-mail: zolyusop@econ.upm.edu.my
}

\begin{abstract}
This paper examines ASEAN economic integration and its ability to promote intra-ASEAN trade, namely, Indonesia, Malaysia, Philippines, Singapore and Thailand. In order to achieve this goal, a modified gravity model is estimated within autoregressive distributed lag (ARDL) framework, or bounds testing approach for each of the five ASEAN countries based on data from year 1970 to year 2001. The empirical results indicate that the effects of the size of economy on bilateral trade flow in ASEAN are either trade-enhancing or trade-inhibiting dependent on the country-specific. There is evidence that AFTA preferential arrangements are important and prevalent in enhancing intra-ASEAN trade. However, ASEAN countries may not as a whole benefit from the formation of AFTA as the trade deflection might occur in the regional market.
\end{abstract}

Keywords: Free trade area, Trade creation, Trade diversion, Trade deflection, Trade-enhancing, Preferential trade arrangement

\section{Introduction}

The economic emergence of the Association of Southeast Asian Nations (ASEAN) brings not only opportunities but also challenges to each of the member countries. Although ASEAN countries occupy similar geographical area, they are extremely diverse in terms of economic structure and development, political orientation, factor endowments, culture, history and religion. The divergence in income and background are the obvious feature of the ASEAN Free Trade Area (AFTA) member countries. The divergence in background is reflected by the readiness of each nation approaching AFTA dateline. An indicator of readiness can be seen from the members' proposal of the average import tariff with the smaller figures implying the higher degree of readiness while larger figures implying the lower degree of readiness. As observed by Naya and Plummer (1997: pp. 118): "ASEAN economic co-operation had not developed significantly and many scholars felt it couldn't (because of the dominance of politics in the Association) or that it shouldn't (due to the potential effects trade diversion in a region characterized by low level of intra-regional trade)."

From the theoretical standpoint, regional trade agreements' benefits and costs can be portrayed from two perspectives. First, the static effects of economic integration that measured in terms of increasing the effectiveness of production and consumer welfare (Note 1). Second, the dynamic effects of economic integration, affecting the overall economic growth rate of member countries in the long term (Note 2). The static effects include both the trade creation and trade diversion effects, in which they occur directly on the formation of the integration project (Note 3). According to Viner (1950), 
trade creation taking place whenever economic integration leads to a shift in product origin from a domestic producer whose resource costs are higher to a member producer whose resource costs are lower. Whereas, Plumber (1997) and Hassan (2001) view net trade creation as an improvement in the allocation of resources. Trade creation is beneficial to a country because it leads to the contraction of inefficient resources that could be used more effectively elsewhere in the economy. On the contrary, Plummer (1997) and Hassan (2001) argued that trade diversion would worsen the international allocation of resources and shifts production away from comparative advantage. However, the static welfare effect of economic integration that involves trade diversion is ambiguous, depending on the relative strength of these two opposing forces such as innovation of technology (Beaulieua, et al., 2004). Viner (1950) concludes that regional trading arrangements can either increase or reduce world welfare depending upon the relative magnitudes of the trade-creation and trade-diversion effects.

Plummers (1997) relates dynamic effects as a medium term, and are long-term, implications of regional integration and, as such, are likely to be more important than the static effects that they may lead to the economic structure and performance of participating countries may evolve differently than if they had not integrated economically. $\mathrm{He}$ considers four possible areas that define to be "dynamic" in nature and derive directly from regional integration: "economies of scale", "X-efficiency" improvements, changes in investment flows, and the potential for industrial expansion in a developing country context. Hassan (2001) provides a similar view of point and claims that dynamic effects can be viewed as the factors that lead to faster economic growth.

There is a model of bilateral trade suggests that trade diversion or trade creation can be justified misallocation of resource reasons. Empirically, Ramasamy (1995) estimates the negative effect of trade diversion on resource allocation among members of ASEAN and reveals that trade creation is greater than trade diversion for Indonesia, Philippines and Thailand, whereas the reverse is true for Malaysia and Singapore. He concludes that resources will be misallocated in Malaysia as a result of Free Trade Area. However, AFTA will cause a positive gain in the allocation of resources for Indonesia. These are static effects that measuring the impact in the short term only. In the long term, it is possible that the positive dynamic effects of increased competition, economies of scale and the benefits of intra-industry trade far outweigh the short term effects.

Endoh (1999) attributes the effects of bilateral trade to the feature and the transition of trade relations in the Asia-Pacific region during the post-World War II period. He concludes that ASEAN has had no effect of its own on promoting trade among its member countries; the volume of trade among EAEC has been at a high level as compared to the hypothetical trade level since 1960; the amount of trade between EAEC economies and other APEC countries has been growing throughout the post-war period and close trade relations among APEC economies and some other Asian countries.

Besides, there is a broad literature that applies the gravity approach to study the international bilateral trade. Thornton and Goglio (2002), for example, confirm the importance of economic size, geographic distance and common language in intra-region bilateral trade by applying the gravity model. The finding shows that re-exports and membership of ASEAN have been important factors promoting intra-regional trade. In line with this research, Clarete, et al. (2003) also use gravity model to estimate the coefficients of the basic determinants such as the GDP, distance between capitals of trading partners, population, and physical area to explain cross-country trade flows. They reveal that Preferential Trade Areas (PTAs) have augmented trade in Asia. The new AFTA members are less integrated with the world economy as the founding members of this PTA. The PTAs in this analysis have contributed significantly to trade expansion both at the global and regional (Asia and Pacific) level. There is strong evidence that PTAs can create rather than divert trade. The results obtained suggest that PTAs offer a next-best path towards expanding world trade if negotiations for multilateral trade liberalization take a longer time to get completed.

This empirical result is also supported by Frankel (1998), who also used gravity model to detect and quantify a possible intra-regional trade bias by establishing a "norm" of bilateral trade volume based on economic, geographic and cultural factors (Note 4). Frankel concludes that trade is indeed concentrated regionally in formal RTAs such as ASEAN and NAFTA, or less formal grouping such as APEC. Although East Asia has a high level of intra-regional trade concentration, there has been no increase over time. Hence, the rapidly increased in intra-Asian trade can be entirely explained by the rapid growth in the region. On the other hand, the rapidly increased in trade among the APEC countries cannot be entirely explained by the growth of the member countries. APEC has operated as an intensifying trade bloc and its high level of trade is all the more impressive in that the distances are so large.

In their recent study, Elliott and Ikemoto (2004) have investigated the effect of AFTA on world and regional trade patterns, concerning on data for the five founding ASEAN countries by applying a modified gravity equation. They found that trade flows were not significantly affected in the years immediately following the signing of the AFTA agreement in 1993. This reinforces the findings of previous studies. Moreover, they argued that the degree of trade creation was lower than the preceding period (1988-1992). When the gravity equation is re-estimated for intra-ASEAN trade only, nevertheless, they did find some evidence of a positive AFTA effect that, although limited at the beginning stage, gradually increased. They argued that the fall in trade creation immediately following 1993 was the emergence of 
credible competition for market share from the new industrial and exporting powers of China, South American and Eastern Europe.

From the previous literature, obviously, co-operation through economic integration such as free trade areas or preferential trade agreements would lead to an increase (decrease) in trade efficiency (inefficiency) and secure a more (less) economical use of resources in order to increase (decrease) intra-ASEAN trade in the long run. Recently, nevertheless, as AFTA involves different background of economies and being more heterogeneous, thus it faces problem in securing internal implementation though it has obtained the consensus. Each member countries are clearer of their own large external seeking than it is about its internal objectives as well as retains the right to establish its own separate protection against imports from the rest of the world. Obviously, within the current framework of AFTA, each nation is acted as individualistic rather than collaborative or complementary with one another. This non-collective planning and strategies among ASEAN members raises the possibilities of a particularly dark scenario - trade deflection to take place (Note 5).

With the persistence of this unhealthy trend not only makes ASEAN as a whole might not gain collectively from AFTA, indeed all of them might be worse off. Whether ASEAN countries will, as a whole, benefit from the formation of AFTA is still an open question. It is therefore important to ask: Do they really promote trade among members? What are the significant influences on trade linkages or interactions among ASEAN economies - Indonesia, Malaysia, Philippines, Singapore, and Thailand - before and after AFTA? How much do trade patterns change over time among members? In this paper, we re-examine bilateral trade relationship between each ASEAN-Five members in order to discover what determinants of intra-trade that can explain the changing trade patterns.

The first contribution of the paper is to examine and prove a proposition that has existed for many years in the trade-policy literature: there can exist gains (trade creation) from trade due to the economic integration of participating countries, but there will be a loss (trade diversion) resulting from the heterogeneous background of the participating countries. The second contribution is to provide explanations to these issues by exploring the effects of AFTA and crisis on intra-ASEAN besides identifying the factors that explaining the intra-ASEAN trade via a modified gravity model within autoregressive distributed lag (ARDL) framework for each of the five ASEAN countries based on data from year 1970 to year 2001. To the best of our knowledge, there does not exist a formal ARDL modeling framework in which to estimate the intra-trade relationship between ASEAN members.

This paper is organized as follows: section 2 provides some historical background to ASEAN regional co-operation. Section 3 discusses the modified gravity model and its essential features. This section also presents the testing framework of the modified gravity approach within ARDL model. Section 4 discusses the empirical results. Section 5 provides some concluding comments and policy implications on the future of regional integration in ASEAN.

\section{Historical overview in the ASEAN economies}

It could hardly be asserted that the economic co-operation programmes implemented through the establishment of ASEAN were a full success. ASEAN remains to be a loose regional grouping. Each member country still insists on its own independent law and policies, its legal system, and its sovereign right to control and regulate internal activities as well as conduct external relationships, except those mutually agreed in the economic, social and political cooperation programs. Every programme implemented in ASEAN has been agreed among the member countries on a consensus basis. It was only in 1992 that ASEAN began to develop the idea of establishing the ASEAN Free Trade Area, a scheme to strengthen intra-regional economic cooperation to respond to global change. Through Free Trade Arrangement (FTA) member countries are expected to enjoy more positive outcomes from an economic integration. Resulting from the Fourth Summit Meeting, the ASEAN heads of government formally agreed and signed the Singapore Declaration, marking the commitment to intensify economic co-operation in the entire region. Basically, the Declaration is the creation of the ASEAN Free Trade Area (AFTA) in 15 years beginning 1st January 1993.

The main purpose of Free Trade Area in ASEAN is to remove the obstacles to a freer trade among member states. Under AFTA, high tariffs or taxes on traded goods and the quantitative restrictions and other non-tariffs barriers that limit the entry of imports had been abolished. Meanwhile, each ASEAN member country has the right to set its own level of tariffs on imports from non-members. The ultimate objective of AFTA is to increase the competitiveness of ASEAN as a globally competitive production base. AFTA will facilitate efficient utilisation of scarce resources and provides opportunities for the ASEAN member countries to further strengthening their competitive advantage. With the widespread, rapid and sustained economic development, AFTA is expected to narrow the economic gap among the ASEAN member countries through trade-creating effect, improve resource allocation and create greater employment opportunities. Besides, AFTA provides opportunities for the ASEAN producers to enjoy a bigger market of 526 million people and with the GDP capacity of US $\$ 555.3$ billion. Furthermore, AFTA is created for the purpose of complementing the forward and outward-looking ASEAN countries in promoting economic growth through export and investment-promotion strategies. It will further improve the external competitiveness of the ASEAN on the back of substantial trade-creation effects and bigger flows of trade-related investment. As pointed out by Sharma and Chua 
(2000), the complementarity in market size, resource endowment and income level provided enormous possibilities for interactions between countries in either goods or factor markets. For example, Resource-rich countries such as Malaysia and Indonesia can complement resource-poor countries like Brunei and Singapore. On the other hand, countries with high ratios of saving, such as Brunei and Singapore, can channel their investments through foreign investments to countries with low capital resources, like Thailand and Indonesia.

The main mechanism to realize AFTA is the Agreement of the Common Effective Preferential Tariff (CEPT) scheme. The CEPT Agreement allows ASEAN member Countries to reduce their tariffs to $0-5 \%$ on a MFN basis among ASEAN members. However, the ASEAN Economic Ministers Meeting Chiang-Mai, Thailand on $22^{\text {nd }}$ and $23^{\text {rd }}$ September 1994 had reached an agreement to shorten the time frame for the realisation of the AFTA from 15 to 10 years (Note 6). The CEPT scheme will cover nearly $98 \%$ of all tariff lines in ASEAN by the year of 2003 excluded those in the General Exceptions category and sensitive agricultural products. The Fifth ASEAN Summit held in Bangkok, Thailand in December 1995 reaffirmed the commitments of removing all quantitative restrictions and non-tariff barriers (NTBs). This further mandated greater transparency in standards and establishment of mutual recognition arrangements on a bilateral or multilateral basis to facilitate greater intra-regional trade.

The year 1997-1998 Asian crisis was a major turning point. The ASEAN economies and business dynamism in the region has been severely affected by the financial and economic crisis. In order to regain business confidence, enhance economic recovery and promote economic growth, the ASEAN leaders are oblige to be committed in the realization of AFTA as well as to enhance further economic integration of the region. At the 6th ASEAN Summit in year 1998, which was held in Hanoi, the ASEAN leaders adopted measures to accelerate rather than reversed the process of tariff reductions during the year 1997 Asian financial crisis. They agreed that the original signatories to the Agreement on the CEPT Scheme for the AFTA namely, Indonesia, Malaysia, Philippines, Singapore, Thailand and Brunei Darussalam would advance the implementation of AFTA by one year from year 2003 to year 2002. ASEAN accelerated rules permitting 100 per cent non-ASEAN ownership of regional companies has also brought about a clear message that FDI from any region was welcomed in ASEAN.

\section{Data and Methodology}

The core methodology adopted in this study is based upon the gravity model (Note 7) used by Sharma and Chua (2000). This study follows the modify gravity model by using the gross domestic product (GDP) instead of gross national product (GNP) that has been used by Frankel (1993). In this study, the gravity model is conducted by using the time series techniques among ASEAN-5. The modified gravity equation used in this study is in natural logs as shown below:

$$
\begin{aligned}
X_{i j}= & \beta_{0}+\beta_{1}\left(R G D P_{i}^{*} R G D P_{j}\right)+\beta_{2}\left(P G D P_{i}^{*} P G D P_{j}\right)+\beta_{3} T C_{i j}+\beta_{4} D 1 \\
& +\beta_{5} D 2+\varepsilon_{i j}
\end{aligned}
$$

Where $\left(R G D P_{i} * R G D P_{j}\right)$ is the product form of RGDPs for both countries $i$ and $j$ (to take into account the size of the economy), $\left(P G D P_{i} * P G D P_{j}\right)$ is the product form of GDP per capita for both countries $i$ and $j$ (to proxy for the income level), $T C_{i j}$ is the transportation cost to proxies the distance between a particular country $i$ to a particular country $j, D 1$ representing the AFTA preferences, in which a value of one is assigned for period after forming of AFTA and zero is assigned for period before forming of AFTA; and D2 representing the Asian financial crisis, in which a value of one is assigned for period after Asian financial crisis and zero is assigned for period before the crisis.

This study employs the autoregressive distributed (ARDL) bounds test by Pesaran, et al. (2001) to examine the cointegration relationship between trade (X) and a set of explanatory variables. The ARDL technique is selected based on the several considerations of its advantages. Firstly, unlike most of the conventional multivariate cointegration procedures, which are valid for large sample size, the bound test is suitable for a small sample size study (Pesaran, et al., 2001). Given that our sample size is limited with a total of 32 observations only, conducting bounds test will be appropriate. Secondly, the bound test does not impose restrictive assumption that all the variables under study must be integrated of the same order. The test statistic underlying the procedure is similar to the Wald test (or $F$-statistic) in a generalized Dickey-Fuller type regression used to test the significance of lagged levels of the variables under consideration in a conditional unrestricted equilibrium correction model (UECM). It is shown that the asymptotic distributions of both statistics are non-standard under the null hypothesis that there exists no long-run relationship in levels between the variables under concerned, irrespective of whether the regressors are purely I(0), purely I(1) or mutually cointegrated. As such, the order of integration is no more a sensitive issue and thus one could bypass the unit root tests (Note 8).

This procedure allows for testing of at most one long-run relationship and thus requires a zero restriction on one of the off diagonals of the $\lambda$ matrix. The following autoregressive distributed lag, ARDL model will be estimated in order to test the cointegration relationship between the examined gravity model variables: 


$$
\begin{aligned}
\Delta X_{i j, t}= & \beta_{0}+\beta_{1} X_{i j, t-1}+\beta_{2}\left(R G D P_{i}^{*} R G D P_{j}\right)_{t-1}+\beta_{3}\left(P G D P_{i} * P G D P_{j}\right)_{t-1}+\beta_{4} T C_{i j, t-1} \\
& +\beta_{5} D 1+\beta_{6} D 2++\sum_{m=1}^{p} \beta_{7} \Delta X_{i j, t-m}+\sum_{m=0}^{p} \beta_{8} \Delta\left(R G D P_{i} * R G D P_{j}\right)_{t-m} \\
& +\sum_{m=0}^{p} \beta_{9} \Delta\left(P G D P_{i} * P G D P_{j}\right)_{t-m}+\sum_{m=0}^{p} \beta_{10} \Delta T C_{i j, t-1}+\varepsilon_{i j, t}
\end{aligned}
$$

The ARDL procedure involves two stages. At the first stage the existence of the long run relation between the variables under investigation is tested by computing the $F$-statistic for testing the significant of the lagged levels of the variables in the error correction form of the underlying ARDL model. However, the (asymptotic) distribution of the $F$-statistic is non-standard, irrespective of whether the regressors are I (0) or I (1). First, we estimate Equation (1) by ordinary least square (OLS) technique. Second, the presence of cointegration can be traced by restricting all estimated coefficients of lagged level variables equal to zero. That is, the null hypothesis is $\beta_{1}=\beta_{2}=\beta_{3}=\beta_{4}=0$ against its alternative $\beta_{1} \neq \beta_{2} \neq \beta_{3} \neq \beta_{4} \neq 0$. If the computed $F$-statistic is less than lower bound critical value, then we do not reject the null hypothesis of no long-run levels relationship. Conversely, if the computed $F$-statistic is greater than upper bound critical value, then we reject the null hypothesis and conclude that there exists steady state equilibrium between the variables. However, if the computed value falls within lower and upper bound critical values, then the result is inconclusive and knowledge of the order of the integration of the underlying variables is required before conclusive inferences can be made.

The most important trade data source for our analysis of ASEAN trade directions are collected from the Direction of Trade Statistics Yearbook of the International Monetary Fund (IMF). The transportation costs data to proxy the distance between the economies is from the Wan Hai Lines (M) Sdn. Bhd. Real GDP and GDP per capita data are from the World Bank World Development Indicators Database (2002).

\section{Empirical Results and Discussions}

From the results of the ARDL models of the computed $F$-statistics (Table 1), there exists a long-run relationship between the variables of the gravity equation are supported by all the bilateral trade flows among ASEAN-5, namely, Indonesia, Malaysia, Philippines, Singapore and Thailand data. For all countries, the computed $F$-statistic is greater than upper bound critical value, thus we reject the null hypothesis of no long-run levels relationship and conclude that there exists steady state equilibrium among the variables under study. For all the countries, we do not reject the null hypothesis of no residual correlation, ARCH and residual normality for each experiment from first order to fourth order. Meanwhile, we do not reject the null hypothesis of no Ramsey RESET problem for each experiment from first order to third order. The validity and reliability of the model, therefore, is confirmed as the model obeys the classical linear regression model (CLRM) namely, residuals are serially uncorrelated, homoscedasticity, normally distributed and the model is correctly specified.

The empirical results indicate that the overall effects of the size of economy - proxy by GDP - on bilateral trade flow are mixed and inconclusive. In the cases of bilateral trade flows from Malaysia to Indonesia, Malaysia to Thailand, Indonesia to Malaysia, Indonesia to Singapore, Philippines to Indonesia, Philippines to Thailand, Singapore to Thailand, and Singapore to Malaysia, the size of economy is obviously crucial in promoting the bilateral trade flows among the relevant countries significantly and negatively. Although the results are inconsistent with a priori, which implies a positive relationship between the economic size and trade flows, the findings support the Linneman's (1966) and Leamer and Stern's (1970) findings. According to their framework, an increase in economic size leads to less reliance on foreign trade because self sufficiency is achieved with an increasing economic size, thereby reducing trade flows with their trade partners.

On the other hand, the coefficient of GDP for Malaysia to Philippines, Indonesia to Philippines, Philippines to Singapore, Thailand to Indonesia, Thailand to Malaysia, Thailand to Singapore, and Singapore to Indonesia indicate significantly positive sign. This may support the hypothesis that trade increases with the size of the economy, as proven by Brada and Mendez's (1983) and Sharma and Chua (2000). This may suggests that a large domestic market promotes division of labour and thus creates opportunities for trade in a wide variety of goods. Although the coefficient for Malaysia to Singapore, Philippines to Malaysia, and Singapore to Philippines show positive sign, but are insignificant. These findings are in accord to Oguledo and Macphee (1994), in which indicated that the insignificance of the economic size variable might suggest that political and colonial ties are more important than economic sizes.

The income level (GDP per capita) has shown the significant and expected positive sign in the case of bilateral trade flows from Malaysia to Indonesia, Malaysia to Philippines, Malaysia to Singapore, Malaysia to Thailand, Indonesia to Malaysia, Indonesia to Singapore, Indonesia to Thailand, Philippines to Indonesia, Philippines to Malaysia, Philippines to Thailand, Singapore to Malaysia, Singapore to Philippines, and Singapore to Thailand. These results confirmed the idea that the higher the income level, the greater the production capacity and the larger the amount they can export as well as the greater the domestic consumption and import demand. Higher income level has also indicated a greater ability of the exporters to produce and export at a lower cost, all else remaining constant. The positive and significant 
effects of GDP per capita on trade flows reported in the study are in line with Linneman (1966), Aitken (1973), Geraci and Prewo (1977) and Brada and Mendez (1983).

With the exception, the coefficient of the GDP per capita for trade flows between Thailand to Indonesia, and Singapore to Indonesia show a significant negative sign, in which are not in line with theoretical expectation. This may be due to the collapse in the provision of credit caused by their poor balance sheets, weak levels of capitalization, and high levels of foreign debt exposure. With the increased cost of foreign debt service, firms were unable to service this debt or to obtain further credit. In addition, the heavy layoffs and increased unemployment have jeopardized the income level of labour. Thus, the widespread loss of purchasing power reduced the domestic consumption and import demand. Furthermore, the combination of higher Rupiah costs and the disappearance of short-term financing have deteriorated the import of the raw material. It has also brought about the fall in the exports of many industries. The political instability follows by the fall of the Suharto regime as well as the widespread social unrest during 1998, making the Indonesia's economy worse off. Whereas, the coefficient of GDP per capita from Thailand to Malaysia, and Thailand to Singapore that are also significantly negative sign may be explained by the Thailand economy that was seriously affected by the financial crisis impact.

The coefficient of distance variable (TC) for bilateral trade flows from Malaysia to Singapore, Malaysia to Thailand, Indonesia to Thailand, Philippines to Malaysia, Thailand to Indonesia, Thailand to Malaysia, Thailand to Philippines, and Singapore to Indonesia show significant and positive sign. This might be explained by the new technological advances in transportation and telecommunications, in which they have reduced the economic distances among the nations. The coefficient of distance for bilateral trade flows from Malaysia to Indonesia, Malaysia to Philippines, Indonesia to Philippines, Indonesia to Singapore, Philippines to Indonesia, Philippines to Singapore, Philippines to Thailand, Thailand to Singapore, and Singapore to Philippines are in the expected negative sign and significant. This means that distance is an important factor, which influent the volume of goods traded and is generally regarded as a significant barrier to trade. As Krugman (1991) revealed that distance tends to increase the cost of transacting international exchange of goods and services. The farther apart two potential trading partners are, the more costly their bilateral trade, in which it erodes possible gains from trade. The findings are expected because most of the countries in ASEAN are divided by water, and the port facilities are not that advance as compared to industrial countries.

The mixed results between transportation costs and trade, therefore, are not surprising. To some extent, these costs might be expected to depend on geographical factors and can be treated as an exogenous variable. Nonetheless, it is plausible to expect that they would also depend inversely on the development of transport and telecommunications infrastructure. Variations in transport costs across countries may be able to account for differences in their ability to compete in international markets. Thus, differences in the volume and quality of infrastructure across countries may be responsible for differences in transport costs, which in turn, may be able to account for differences in competitiveness (Bougheas, et al., 1999: pp. 170). Indeed, in a recent paper, Limao and Venables (2001) show that raising transport costs by $10 \%$ reduces trade volumes by more than $20 \%$.

The significant and positive sign of dummy variable representing AFTA preferential (D1) of bilateral trade flows from Malaysia to Indonesia, Indonesia to Philippines, Indonesia to Thailand, Thailand to Indonesia, Thailand to Philippines Singapore to Indonesia, and Singapore to Philippines imply that the importance and prevalence of the formation of AFTA preferential arrangements in the intra-ASEAN trade flows. On the other hand, the significance negative sign of D1 of the bilateral trade flows from Malaysia to Philippines, Malaysia to Singapore, Malaysia to Thailand, Indonesia to Malaysia, Thailand to Malaysia, and Indonesia to Singapore may suggest that ASEAN as a whole does not gain collectively from the formation of AFTA. This may due to the existence of trade deflection in the regional market. Trade deflection will shrinks tariff revenue that those members would otherwise collect, in which tariff revenues are in effect redistributed in favour of low-tariff members as well as weakens the protective impact of high-tariff members' trade policies. It could be seen that the lower the average CEPT tariff rates, the higher the total trade amount except for the Philippines and Indonesia because of their serious macroeconomic difficulties, which were aggravated by political upheaval. For instance, by comparing the breakdown of intra-ASEAN and inter-ASEAN trade from the period of year 1981-2000, nearly half of ASEAN's intra- and inter-ASEAN trade originate in Singapore that has the lowest average CEPT tariff rates. Singapore bilateral pacts with non-ASEAN countries would result in massive trade deflection into the regional market. With the persistence of this unhealthy trend not only makes ASEAN as a whole might not gain collectively from AFTA, indeed all of them might be worse off.

The significant negative sign of the dummy variable representing Asian financial crisis (D2) of the bilateral trade flows from Malaysia to Indonesia, Malaysia to Singapore, Malaysia to Thailand, Indonesia to Philippines, Indonesia to Singapore, Philippines to Singapore, Singapore to Malaysia, and Singapore to Indonesia mean that crisis was reduced the bilateral trade flows. During the Asian Financial crisis, once Thailand floated the baht, countries lose competitiveness when their trading partners devalue. Therefore, they are more likely to be attacked and to devalue themselves. Currency devaluation increase competitiveness of a country's goods in international market, thus promoting 
exports and enhancing output growth. Whereas, the depreciation of domestic currency would increase the costs of imported inputs, eventually lead to contraction effects in the economy. Thus, during crisis, ASEAN countries increase their exports to developed countries while reduce their imports from neighbouring countries. Elliott and Ikemoto (2004) provide one explanation for the weakening of this negative import diversion effect after the Asian crisis. They argue that “... this situation may reflect the consensus that prior to this date that although ASEAN's success was based on its outward orientation, perceived problems of credibility and confidence in the region by the industrialized world meant that ASEAN countries were forced to turn inwards and to focus on their local markets." (pp. 17).

On the other hand, the dummy variable representing Asian financial crisis (D2) of the bilateral trade flows from Indonesia to Malaysia indicates a significant and positive sign. This may explain the upheavals of the Asian crisis did not affect the bilateral trade flows. However, the exceptional significant and positive sign of the coefficient D2 from Indonesia to Malaysia may be implied that the crisis has invoked the ASEAN sense of belonging among the member countries and thus, enhancing a greater level of economic co-operation. Furthermore, the contagion effect of the financial crisis has further demonstrated their high degree of economic inter-dependence, and therefore, highlighted the need for some policy co-ordination. For instance, the consolidation of Malaysia-Indonesia Trade and Economic relations through the revival of the Indonesia-Malaysia-Thailand Growth Triangle (IMT-GT) that have been stalled since the Asian financial crisis broke out in year 1997 by revisiting the basic regional co-operation strategies and redefining necessary support measures. Furthermore, there is an indication that Korea and Malaysia are among Asian countries experiencing the fastest path of recovery after crisis. Perhaps the significant positive sign might be due to the composition of trade (exports and imports) that are complimentarily rather than competitively to each other not affected by crisis.

\section{Concluding Remarks and Policy Implications}

Using a modified gravity equation, this paper examines ASEAN economic integration and its ability to promote intra-ASEAN trade, namely, Indonesia, Malaysia, Philippines, Singapore and Thailand within ARDL framework for each of the five ASEAN countries based on the annually data from 1970 to 2001. The analysis leads to the following conclusions. First, the effects of the size of economy on bilateral trade flow in ASEAN are mixed and inconclusive. Therefore, we could conclude that the size of economy can be either trade-enhancing or trade-inhibiting dependent on the country-specific. Second, an increase in the GDP per capita of the ASEAN country tends to increase the trade flows to the particular country. Third, the effects of the distance on bilateral trade flow in ASEAN are indeterminate. Distance can be either negatively or positively related to ASEAN trade flows, in which indicating the provision of improved accessibility that can result in reduced transport costs and thus reduced the economic distances among the nations. Fourth, although there exists importance and prevalence of the formation of AFTA preferential arrangements in enhancing intra-ASEAN trade, ASEAN countries may not as a whole benefit from the formation of AFTA. ASEAN countries as a whole will be worse off if trade deflection take place in the regional market. Finally, during crisis, ASEAN countries increase their exports to developed nation while reduce their imports from their neighbouring countries.

The outcomes of AFTA have not been as good as expected, the findings confirmed that policy makers of the ASEAN member countries should be more concerned in the effort of enhancing the co-operation in intra-ASEAN trade especially dealing with external shock collectively. With an understanding of the channel through which these factors influence trade flows, policy makers will be essential in suggesting and formulating appropriate policies in forming the future trade arrangement and the feasibility of a substantial expansion of regional trade. There are some issues derived from the findings should be concerned by relevant policy makers. First, countries should make efforts to reduce transaction costs between ASEAN regions to achieve a deeper economic integration since distance is among the main determinants of trade. Second, ASEAN countries need to improve their togetherness or strengthen their cooperative spirit through AFTA by identifying the strengths and weaknesses of each member country.

Third, if there is an increase in trade deflection as a result of the bilateral free trade agreement, it has to redesign and enforcement of AFTA's rules of origin requirement to make it difficult for imports from non-ASEAN members to be deflected through lowest tariff country. As suggested by Bagwell and Staiger (2004), the potential for opportunistic bilateral agreements is severe when there are no rules. They have proven that the welfare of a nonparticipating government is preserved in the presence of any bilateral agreement that respects the principles of reciprocity and nondiscrimination. As a consequence, they suggest that preferential tariff agreements, which are permitted under the special exception to most-favored-nation (MFN) granted by GATTs Article XXIV, represent a possible route to opportunistic bilateral agreements (pp. 24). Therefore, a more solid bilateral trade agreement should be recommended by the policy makers to ensure each ASEAN member will benefit from AFTA.

\section{References}

Aitken, N.D. (1973). The effect of the EEC and EFTA on European Trade: a temporal cross-section analysis. American Economic Review, 5, 881-892. 
Anderson, J.E. (1979). A theoretical foundation for a gravity equation. American Economic Review, 69, 106-116.

Bagwell, K. \& Staiger, R.W. (2004). Multilateral trade negotiations, bilateral opportunism and the rules of GATT/WTO. Journal of International Economics, 63, 1-29.

Beaulieua, E., Benarroch, M. \& Gaisford, J. (2004). Trade barriers and wage inequality in a North-South Model with technology-driven intra-industry trade. Journal of Development Economics, 75, 113-136.

Beckerman, W. (1956). Distance and the pattern of Intra-European trade. Review of Economics and Statistics, 39, 31-38.

Bergstrand, J.H. (1985). The gravity equation in international trade: some microeconomic foundations and empirical evidence. Review of Economics and Statistics, 67, 474-481.

Bougheas, S., Demetriades, P.O. \& Morgenroth, E.L.W. (1999). Infrastructure, transport costs and trade. Journal of International Economics, 47, 169-189.

Brada, J.C. \& Mendez, J.A. (1983). Regional economic integration and the volume of intra-regional trade: a comparison of developed and the developing country experience. KYKLOS, 36, 92-105.

Clarete, R., Edmonds, C. \& Wallack, J.S. (2003). Asian regionalism and its effects on trade in the 1980s and 1990s. Journal of Asian Economics, 14, 91-129.

Elbadawi, I. (1997). The impact of regional trade and monetary schemes on intra-subSaharan Africa trade. In A. Oyejide, I. Elbadawi and P. Collier (Eds.), Regional integration and trade liberalization in SubSaharan Africa. Volume 1: Framework, Issues and Methodological Perspectives, pp. 210-255, London: Macmillan Press.

Elliott, R.J.R. \& Ikemoto, K. (2004). AFTA and the Asian crisis: help or hindrance to ASEAN intra-regional trade? Asian Economic Journal, 18, 1-23.

Endoh, M. (1999). International trade - economic aspects - Asia, Asia-Pacific Economic Cooperation (Organization). Journal of Asian Economics, 10, 571-589.

Engle, R.F. \& Granger, C.W.J. (1987). Cointegration and error correction: representation, estimation and testing. Econometrica, 55, 251-276.

Evenett, S.J. \& Keller, W. (2002). On theories explaining the success of the gravity equation. Journal of Political Economy, 110, 281-316.

Frankel, J. A. (1993). Is Japan creating a yen block in East Asia and the Pacific? In Jeffrey A. Frankel and Miles Kahler (Eds.), Regionalism and rivalry: Japan and the United States in Pacific Asia. pp. 53-85. University of Chicago Press, Chicago. (reprinted in R. Garnaut and P. Drysdale (Eds.), Asia-Pacific Regionalism: readings in international economic relations, pp. 227-249. Sydney: Harper Educational Publishers).

Geraci, V.J. \& Prewo, W. (1977). Bilateral trade flows and transport costs. Review of Economics and Statistics, LIX, 67-74.

Granger, C.W.J. \& Newbold, P. (1974). Spurious regressions in econometrics. Journal of Econometrics, 2, 111-120.

Gujarati, D.M. (2003). Basic econometrics. $4^{\text {th }}$ Edition, Singapore: McGraw-Hill.

Hassan, M.K. (2001). Is SAARC a viable economic block? evidence from gravity model. Journal of Asian Economics, $12,263-290$.

Helpman, E. \& Krugman, P.A. (1985). Market structure and foreign trade. Cambridge: MIT Press.

Krugman, P. (1991). The move toward free trade zones. In Policy implications of trade and currency zones: A symposium sponsored by the Federal Reserve Bank of Kansas City, Kansas City: Federal Reserve Bank of Kansas City, pp. 7-41.

Leamer, E.E. \& Stern, R.M. (1970). Quantitative international economics. Boston: Allyn and Bacon.

Limao, N. \& Venables, A.J. (2001). Infrastructure, geographical disadvantage and transport costs. The World Bank Economic Review, 15, 451-479.

Linnemann, H. (1966). An econometric study of international trade flows. Amsterdam: North-Holland.

Oguledo, V. I. \& Macphee, C.R. (1994). Gravity models: a reformulation and an application to discrimination trade arrangements. Applied Economics, 26, 107-120.

Pesaran, M.H., Shin, Y.C. \& Smith, R.J. (2001). Bound testing approaches to the analysis of level relationship. Journal of Applied Econometrics, 16, 289-326.

Plummer, M.G. (1997). ASEAN and the theory of regional economic integration. ASEAN Economic Bulletin, 14, 202-214. 
Ramasamy, B. (1995). Trade diversion in an ASEAN free trade area. ASEAN Economic Bulletin, 12, 10-17.

Sanso, M., Cuairan, R. \& Sanz, F. (1993). Bilateral trade flows, the gravity equation, and foundation form. Review of Economics and Statistics, 75, 266-275.

Sharma, S.C. \& Chua, S.Y. (2000). ASEAN: economic integration and intra-regional trade. Applied Economics Letters, 7, 165-169.

Thornton, J. \& Goglio, A. (2002). Regional bias and intra-regional trade in Southeast Asia. Applied Economics Letters, 9, 205-208.

Viner, J. (1950). The economics of customs unions. In The customs union issue, Chapter IV, New York: Carnegie Endowment for international Peace, pp. 41-81.

\section{Notes}

Note 1. The static effects of Preferential Trading Groups generally refer to onetime changes in the allocation of resources or efficiency.

Note 2. In order to estimate the overall national welfare effect, these two effects have to integrate together to obtain an overall picture of the economic impact of the regional bloc on a member country.

Note 3. Jacob Viner (1950) defined trade diversion as taking place whenever there is a shift in product origin from non-member producer whose resource costs are lower to a member country producer whose resource costs are higher. Trade creation is the net volume of new trade created by forming the trade bloc. It causes two kind of gain in an economy: gains on extra consumption of the product and gains on replacement of higher-cost production by lower-cost partner production.

Note 4. Other variables was entered into the equation include per capita incomes, and dummy variables indicating whether the pair share a common border or common language.

Note 5. Trade deflection refers to the import penetration of the ASEAN market by non-ASEAN countries through country that has the lowest tariff, and for subsequent re-exports to the rest of the ASEAN countries by utilizing the AFTA Common Effective Preferential Tariff (CEPT). Trade deflection will lead to greater inefficiency by stimulating production in the partner country in areas that has intra-regional comparative advantage but comparative disadvantage at the global level, in which will detriment the economic development prospects of its member states. If AFTA were agreed to be more collaborative but then led to greater trade deflection and inefficiency that are welfare reducing, this could threaten the development strategies of the ASEAN countries.

Note 6. The time frame for fully implementing AFTA has been set at 10 years for the more advanced economies of ASEAN and 15 years for the new ASEAN members.

Note 7. The gravity model has been using extensively to provide a natural framework and a useful multivariate approach for assessing the impact of regional trading blocs on the level and direction of bilateral trade flows. See Helpman and Krugman (1985) for the underlying theory of the model. Anderson (1979), Bergstrand (1985), Sanso, et al. (1993) and Evenett and Keller (2002) provide further discussion on the use of the gravity approach in trade literature. Moreover, Elbadawi (1997) reveals that gravity equation is superior in terms of its ability to incorporate the factors that cannot be accommodated by the conventional factor endowment theory such as intra-industry trade (by considering market size and scale economies) and the efficiency of resources reallocation following trade liberalisation (by introducing dummy variables).

Note 8. In order to avoid spurious regression, prior to conventional cointegration test such as the Engle and Granger (1987) bivariate test, one needs to conduct unit root tests to make sure that all system's variables are integrated of the order (Granger and Newbold, 1974; Gujarati, 2003). 
Table 1. The results of bilateral trade between ASEAN-Five based on Equation (2)

\begin{tabular}{|c|c|c|c|c|}
\hline \multicolumn{5}{|c|}{ Trade Flows from Malaysia } \\
\hline Variable & Indonesia & Philippines & Singapore & Thailand \\
\hline RGDP*RGDP & $-17.479 * * *$ & $0.410^{* *}$ & 0.364 & $-18.468 * * *$ \\
\hline PGDP*PGDP & $24.107 * * *$ & $2.143 * * *$ & $1.382 *$ & $28.215 * * *$ \\
\hline $\mathrm{TC}$ & $-7.363 * * *$ & $-0.537 * * *$ & $0.645^{* *}$ & $4.533^{* *}$ \\
\hline D1 & $0.901^{* *}$ & $-0.075^{* *}$ & $-0.120 * * *$ & $-0.276^{*}$ \\
\hline D2 & $-0.209 *$ & -0.002 & $-0.072 *$ & $-0.315^{*}$ \\
\hline Adjusted $\mathrm{R}^{2}$ & 0.611 & 0.801 & 0.793 & 0.636 \\
\hline Computed F statistic & $8.613 * * *$ & $17.537 * * *$ & $6.661 * * *$ & $4.704^{* *}$ \\
\hline \multicolumn{5}{|c|}{ Trade Flows from Indonesia } \\
\hline Variable & Malaysia & Philippines & Singapore & Thailand \\
\hline RGDP*RGDP & $-11.405^{* *}$ & $4.586^{* *}$ & $-49.930^{* * *}$ & -12.703 \\
\hline PGDP*PGDP & $25.425^{* * *}$ & 1.716 & $64.292 * * *$ & $23.688^{*}$ \\
\hline $\mathrm{TC}$ & -2.416 & $-3.891 * * *$ & -22.635 & $6.817^{*}$ \\
\hline D1 & $-3.125 * * *$ & $0.154 * * *$ & $-0.641 * *$ & $0.998^{*}$ \\
\hline $\mathrm{D} 2$ & $2.755^{* * *}$ & -0.112 & $-0.979 * * *$ & 0.077 \\
\hline Adjusted $\mathrm{R}^{2}$ & 0.971 & 0.965 & 0.865 & 0.762 \\
\hline Computed F statistic & $59.988 * * *$ & $95.498 * * *$ & $19.812 * * *$ & $6.844 * * *$ \\
\hline \multicolumn{5}{|c|}{ Trade Flows from Philippines } \\
\hline Variable & Indonesia & Malaysia & Singapore & Thailand \\
\hline RGDP*RGDP & $-20.712 * * *$ & 0.257 & $1.065^{* * *}$ & $-6.693 * *$ \\
\hline PGDP*PGDP & $29.546^{* * *}$ & $3.413 * * *$ & 0.247 & $13.416^{* *}$ \\
\hline $\mathrm{TC}$ & $-3.307 * *$ & $0.896^{*}$ & $-1.885^{* * *}$ & $-2.203 * *$ \\
\hline D1 & 0.018 & -0.055 & -0.001 & -0.145 \\
\hline D2 & 0.009 & -2.246 & -0.251 & -0.049 \\
\hline Adjusted $\mathrm{R}^{2}$ & 0.904 & 0.737 & 0.900 & 0.766 \\
\hline Computed F statistic & $11.073^{* * *}$ & $11.149 * * *$ & $15.890^{* * *}$ & $5.178^{* *}$ \\
\hline \multicolumn{5}{|c|}{ Trade Flows from Thailand } \\
\hline Variable & Indonesia & Malaysia & Philippines & Singapore \\
\hline RGDP*RGDP & $27.904^{* * *}$ & 1.829 & -2.128 & $6.334 * *$ \\
\hline PGDP*PGDP & $-38.603^{* * *}$ & -0.794 & -4.404 & $-7.672 * *$ \\
\hline $\mathrm{TC}$ & $28.297 * * *$ & $2.674 * *$ & $2.602 * *$ & $-1.285^{* *}$ \\
\hline D1 & $5.955^{* * *}$ & 0.093 & $0.240^{*}$ & -1.285 \\
\hline $\mathrm{D} 2$ & -0.203 & $-0.254 * *$ & -0.120 & 0.005 \\
\hline Adjusted $\mathrm{R}^{2}$ & 0.877 & 0.755 & 0.746 & 0.834 \\
\hline Computed F statistic & $8.061 * * *$ & $5.310^{* *}$ & $15.052 * * *$ & $11.793 * * *$ \\
\hline \multicolumn{5}{|c|}{ Trade Flows from Singapore } \\
\hline Variable & Indonesia & Malaysia & Philippines & Thailand \\
\hline RGDP*RGDP & $13.745^{* *}$ & $-1.592 * * *$ & 0.401 & $-2.598 * *$ \\
\hline PGDP*PGDP & $-17.745^{* *}$ & $3.842 * * *$ & $1.815^{* *}$ & $5.157 * * *$ \\
\hline $\mathrm{TC}$ & $2.489^{* *}$ & -0.012 & $-0.365^{*}$ & 0.529 \\
\hline D1 & $0.464 * *$ & 0.001 & $0.132 * * *$ & $0.132 * * *$ \\
\hline D2 & $-0.390 * *$ & $-0.029 *$ & -0.034 & -0.019 \\
\hline Adjusted $\mathrm{R}^{2}$ & 0.786 & 0.865 & 0.889 & 0.774 \\
\hline Computed F statistic & $14.333^{* * *}$ & $12.905^{* * *}$ & $17.557 * * *$ & $6.814 * * *$ \\
\hline
\end{tabular}

\section{Lower and Upper Bound Critical Value of F-Statistic in Bound Test for}

\begin{tabular}{ccc}
\hline Critical values (F test) & Lower bound & Upper bound \\
\hline $10 \%$ & 2.72 & 3.77 \\
$5 \%$ & 3.23 & 4.35 \\
$1 \%$ & 4.29 & 5.61
\end{tabular}

Note: The LR Coeff. refers to the long-run coefficient. The next column contains the Jarque-Bera statistic for residual normality. The figure in the next column B-G is the Breusch Godfrey Serial Correlation LM test. The final two columns contain ARCH LM Test and Ramsey RESET Stability Test. The Figures in parenthesis beside the F-statistic are the probability of the test. The upper and lower bounds for critical values refers to the distribution of the F-statistic under the null hypothesis when the variables are individually $\mathrm{I}(1)$ and $\mathrm{I}(0)$ respectively.

Source: Pesaran et al. (2001, p.300)

Table CI (iii) Case III: Unrestricted intercept and no trend

The asterisks indicate the following levels of significance: $* 10 \%, * * 5 \%, * * * 1 \%$. 